Jesson, Stuart ORCID:

https://orcid.org/0000-0001-8826-0314 (2015) Traces of resurrection: the pattern of Simone Weil's mysticism. In: Cattoi, Thomas and Moreman, Christopher M., (eds.) Death, dying, and mysticism : the ecstasy of the end. Palgrave

Downloaded from: http://ray.yorksj.ac.uk/id/eprint/799/

The version presented here may differ from the published version or version of record. If you intend to cite from the work you are advised to consult the publisher's version:

Research at York St John (RaY) is an institutional repository. It supports the principles of open access by making the research outputs of the University available in digital form. Copyright of the items stored in RaY reside with the authors and/or other copyright owners. Users may access full text items free of charge, and may download a copy for private study or non-commercial research. For further reuse terms, see licence terms governing individual outputs. Institutional Repository Policy Statement

\title{
RaY
}

Research at the University of York St John

For more information please contact RaY at ray@yorksj.ac.uk 


\section{Traces of Resurrection: The Pattern of Simone Weil's Mysticism}

In her "Letter to a priest", Simone Weil makes the following, typically bold, assertion concerning belief in the resurrection: "Hitler could die and return to life again fifty times, but I should still not look upon him as the Son of God. And if the gospel omitted all mention of Christ's resurrection, faith would be easier for me. The Cross by itself suffices me." "This statement as has often served as an indication that Weil's version of Christian mysticism has no place for the resurrection. Throughout the collection of short essays, articles and notebooks produced at the end of her life Weil reflects frequently, in profound and intriguing ways, on the significance of death, its effect on human thought and its place in moral and spiritual life. Not only is death "the source of all untruth and of all truth for men", ${ }^{2}$, the crucifixion of Christ becomes the centre not only of her spirituality, but also of her metaphysics; creation, for Weil, is the cross that crucifies God. ${ }^{3}$ In some of the more extreme formulations scattered through the notebooks, in particular, Weil gives that impression that she sees life as a cosmic mistake that it is the task of spiritual life to rectify, through acceptance of death: "[b]irth involves us in the original sin, death redeems us from it." ${ }^{, 4}$ Death is the humiliating destiny of all finite creatures, but if one can refuse the various compulsive ways there are of evading the thought of this, and consent to, or even love this necessity, one thereby participates in the process of "decreation", the eradication of the autonomous self. All this adds to the sense that the deepest structures of Weil's thought support the terse statement above: hers is a mysticism of death, not resurrection.

In what follows I examine the basic shape, or pattern, of Weil's understanding of mystical insight and/or transformation. I then proceed to explore the theological significance of certain conceptual tensions that appear within this understanding, tensions which relate closely to her ambivalence toward the idea of resurrection.

\section{Losing and Saving One's Life.}

A particularly notable entry from Simone Weil's Marseilles notebook states that real spiritual awakening is like death: “[o]ne must place one's life in something one cannot touch on any account. It is impossible. It is a death. It means no longer being alive. And that is exactly what is wanted." Before examining Weil's work in detail, then, I would like to introduce a set of conceptual issues through examination of one of the most important sayings attributed to Jesus of Nazareth:"[t]hose who want to save their life will lose it, and those who lose their life for my sake will save it". ${ }^{6}$ In an analogous way, this saying suggests that death may be less opposed to life than one might expect. The saying warns that when it comes to the ultimate "saving" of life, all is not as it seems: loss can be gain, and the desire to gain may lead to loss. At first glance, the saying appears to announce a 
dramatic reversal of perspective, and by doing so, to put the human capacity to evaluate, and to act based on such evaluation, into question.

Upon closer examination, however, an important aspect of the saying complicates the picture somewhat; the desire for life. As we will see, Weil tends to see the determinative factor in human life as being the desire for the good, and is interested primarily in how this desire can be redeemed from its distorted forms, and rarely talks about the idea of desiring one's "life" as an energy to be transformed or harnessed. The gospel saying rests on the assumption that although one may not know exactly what it is that one desires when one desires "one's life", one is right, nonetheless, to desire it. The verse that immediately follows in Mark's version makes this clear: "For what will it profit them to gain the whole world and forfeit their life? Indeed, what can they give in return for their life?" Life's value is such that it cannot be measured by any comparison, or be the subject of any exchange. And indeed, it is the concern for one's life that would cause one to listen to such wisdom, for if one did not much care either way whether one "gained" or "saved" one's life, then neither the warning nor the promise would be of any interest. It is because one wants to live- even if one is not entirely clear on what one wants when one wants to live - that at the saying grabs one's attention. However, the desire or pursuit that the immeasurable value of one's life inspires is ambiguous, and subject to warning and scrutiny; the question it, seems, is not of whether to desire one's life, but of how. As we will see, in analogous way, for Weil it is not a case of whether one desires the good, but of how; at what "level" one places, or conceives of, this good.

If the saying is unintelligible apart from the assumed desire to "save" one's life, one may well wonder whether an overly philosophical interpretation may miss the eschatological dimension of these words: alongside the appearance of a principle concerning evaluation (that things are not as they seem; that to seek to secure possession of "one's life" is to lose it; that apparent loss is really gain) is something much more like a promise: those who lose their lives "for my sake" will gain it; that is, they will in fact attain that which they desired. It is in hope of actually gaining one's life, not simply of learning to see or value it differently, that the disciple is prepared to choose to lose their life. Two obvious ways of understanding this text present themselves, on one hand, eschatologically, as an expression of a promise; on the other handy, more rationally or philosophically, as an articulation of a principle.

An important question also arises here concerning the distinction between saving and losing one's life, and, presumably then, the difference between living and dying. The whole force of the saying depends on the distinction between loss and gain, losing and saving, and yet at the same time, in all these cases, these distinctions seem close to dissolving. It seems as though this instability is crucial to the transformative potential of these ideas: one may turn out to have been fundamentally mistaken not just about what it means to die, but about what one's "life" really was. As we will see, 
many of the most interesting of Weil's reflections on mystical experience depend on the distinction between emptiness and fullness, hunger and satiety, life and death, whilst at the same time seeming to suggest a fundamental upheaval of these distinctions.

This issue can also be discerned in the "beatitudes". Each beatitude follows the same pattern, with a group defined by a characteristic linked to state that is announced as "blessing". However, the relationship between the present condition and the "blessedness" that corresponds to it can be construed in a number of different ways. Perhaps most obviously, some of these sayings seem to affirm that despite their condition the poor in spirit, the meek, the grieving, or the persecuted are, or will be, blessed. The blessing that is the coming of the kingdom does not respect the distinctions that usually distinguish the fortunate from the unfortunate, just as the sun shines on the just and the unjust. And so blessedness may be absent—or hidden — at present but it is nevertheless still obvious - it consists in receiving the kingdom of heaven, in inheriting the earth, in being comforted. One does not have to be told why one is blessed in inheriting the earth, or in being comforted; such things are a blessing, and there is nothing counter-intuitive about the nature of the blessing, only the in the divine choice of recipient.

However, another logic also suggests itself through some of the sayings. The merciful will receive mercy, surely, because of the mercy they have showed; the pure in heart will see God because that was what they desired above all else; those that hunger for justice or righteousness are rewarded according to their hunger. These sayings, then, may announce a completion in which the full significance of present actions or attitudes is fully developed and recognized; the peacemakers are finally named as the children of God they always were. In the former case, the difference between hardship and reward is relatively stable; in the latter case, slightly less so: perhaps certain kinds of hunger are already a blessing, however well-disguised. Finally, and perhaps most problematically, the first and last of the beatitudes end with "for theirs is the kingdom of heaven", suggesting, perhaps that the kingdom of heaven is already present in poverty of spirit and persecution, and that the values of the kingdom are plainly and simply opposed to earthly values.

But then, if poverty of spirit and persecution can be manifestations of the kingdom (persecution in particular, is described as being a sign of one's inheritance of the kingdom, the mark of an authentic prophet), what is it that makes inheritance of this kingdom a blessing, rather than a curse? If the persecuted are receiving the kingdom of heaven in and through their persecutions, why should one desire this kingdom at all $?^{7}$ In other words, there is also the hint here that what is announced is an inversion of ordinary human valuation. But proclaiming an inversion of human values, affirming that wealth is poverty, weakness is strength, and suffering, joy, is far from straightforward. If it is to be the case that poverty can manifest a kind of wealth, what is it that makes this poverty wealth, if not wealth? Speech rebels against the attempt to simply invert values, because articulating such an 
inversion requires an affirmation: if all values are overturned on what basis does one affirm anything what is it that one is doing when one affirms $?^{8}$ If the blessings of the kingdom appear as paradoxically opposed to all usual notions of blessing, why should one count them as blessings at all?

The beatitudes seem, then, to suggest all three of these dynamics (and probably more), and in each of them the values of the kingdom are at a different distance from, and in a different kind of relationship to, mundane valuation, and distinctions that such valuation perceives. In the same way, in the saying about the losing and saving of life, there is the hint of a dramatic subversion, inversion or reversal of perspective, but at the same time, there is no wholesale rejection of one's natural desire for life. My suggestion, here, is that the particular power that these sayings possess rely on this ambiguity. It could be that one finds out that in the kingdom of heaven, true value is almost the reverse of what one expected, such that one finds one was not only looking in the wrong place, but looking for the wrong thing in the first place (as Paul seems to suggest at the beginning of his first letter to the Corinthians). Equally, however, it could be that one discovers how to find the very thing one had longed for. Although I do not have the space to justify the assumption here, I will be assuming that this ambiguity, or instability, correlates in some way to the basic shape of the Christian narrative: in the resurrection, the crucified Christ is re-presented, and the cross is given meaning. But because the meaning of this death is only given, presented, or recovered through its undoing, there is no simple presentation whatever it is that is demonstrated, achieved or exemplified by the cross. The resurrection presents and transforms, or transforms as it presents: this leaves a tremendous ambiguity as to how we can see meaning in death, or indeed, see meaning in a particular approach to death as a way of living. If the death of Jesus can be said to bring life, we are left with the question of what, in this case, we mean by "death", just as, if it is the crucified Jesus who is raised to life, we are left with the question of what, in this case, is meant by "life".

In what follows I will try to follow similar conceptual contours as they appear in a number of important passages from Simone Weil's religious writings, especially those that attempt to articulate moments of mystical upheaval, and which are concerned with the transformative potential of an encounter with the thought of death, emptiness or "void".

\section{Death, Imbalance and the Void}

One can see in Weil's work the conviction that one's orientation towards one's death is somehow determinative of one's whole being. The acceptance of death is linked with a traumatic reorientation of the whole of one's life, which is described in a number of different ways, with different images and metaphors, although we will only have space to examine two of these fairly briefly.

Firstly, Weil's understanding of the operation of human desire, thought and action is often expressed in terms of compensation, balance and the search for equilibrium. For example, one might 
hope for an expression of praise or thanks that seemed proportional to the energy one imagines oneself to have expended in a particular task, or revenge in proportion to the indignity one imagines one has suffered, and so on. ${ }^{9}$ Weil often links this search for balance with the idea that suffering of various kinds can be thought of as a loss of energy; we are prepared to lose energy for the sake of some future gain, but the thought of a loss of energy without compensation is intolerable. Weil sees this tendency as the source of all manner of deception, as the search for equilibrium is "bad because imaginary"; we are left perpetually striving after an equilibrium that never comes because it is impossible. ${ }^{10}$ Because one continually sees the world through the lens of the desired equilibrium, one never pays attention to things as they are, but "cloaks" them with the thought of the satisfaction, restitution, compensation or reward they are imagined to promise us. ${ }^{11}$ However, Weil thinks that this tendency is deeply rooted in life itself, insofar as each living thing acts as an inside that appropriates what lies outside it for its own purposes, for its own future. ${ }^{12}$ It follows, then that to contemplate things as they are, "unshrouded by some imagined future" is to see things as though one were dead; "[o]ne has to be dead to be able to see things in their nakedness". ${ }^{13}$

In one sense, then, to refuse to seek compensations or balance-whether this is through the act of forgiveness, through accepting a lack of recognition or reward, or through honestly attending to the reality of some present suffering - is also to accept death, as she notes memorably on one occasion: "[t]o forgive debts. To accept the past without asking for future compensation. To stop time at the present instant. This is also the acceptance of death." ${ }^{, 14}$ Conversely, the dynamic that she describes as "the search for equilibrium" is itself the manifestation of the denial of death. There is a sense in which death is the ultimate sign of imbalance, for it marks the point beyond which no counterbalance, repayment or compensation is possible, and marks out our lives as essentially unbalanced and unfinished. To accept death is to accept that one's vital energy is essentially limited, and that one is destined to lose all of it. As a result, the thought of death itself calls for a "counter-weight"; here she has in mind the way that the meaning that is sought in life may often be a way of trying to produce something that defies, resists or survives death. ${ }^{15}$ The thought of death produces a panicked reaction, in which one seeks an opposite to cancel it out, but this reaction in fact prevents life being loved as what it is, because all valuations based on the threat of death simply turn life into death's opposite. ${ }^{16}$ In this way, it is only the contemplation and acceptance of death that reveals life in its contingent finitude — which is its reality—rather than a mere counterweight to death. This is seen in one of the notebook entries that were compiled in the collection Gravity and Grace:

If we go down into ourselves we find that we possess exactly what we desire. If we long for a certain being (who is dead), we desire a particular, limited being; therefore, necessarily, a mortal, and we long for that special being "who" ... "to whom" ..., etc., in short that being who died at such and such a time on such and such a day. And we have that being-dead. ${ }^{17}$ 
Here the point is not that this change in perspective removes the pain of loss, but that the pain of loss is now the way in which reality is being given to us, insofar as it is the result of the limited particularity which was part and parcel of their very being.

To summarise, then, the refusal of compensatory psychological mechanisms involves a kind of death, insofar as it means to see the world in its own reality, free of the distortion produced by the drive to continue in one's own existence. On the other hand, it is death itself which produces this compulsive form of life; death is both poison and cure, a pharmakon.

Using a slightly different set of concepts and related images, Weil makes a very similar point in terms of the attempt to "fill the void". "Void" is experienced primarily in terms of the impossibility of desire, and the meaninglessness of suffering. ${ }^{18}$ One of Weil's deepest convictions seems to have been that the experience of being human in the world was essentially the experience of an insatiable desire for something inaccessible, or the experience of an absence - the absence of any final good "here below". ${ }^{19}$ The desire for the good is not so much something one has, as something one is,${ }^{20}$ and yet this desire is for something inaccessible and absent. ${ }^{21}$ To accept this is to accept that the hungry core of one's being is destined to remain unsatisfied, and that nothing that one can obtain, or even aim at, reduces this tension. This means that there is a kind of impotence and emptiness at the heart of one's own being, and to accept this means to surrender one's capacity for self-determination. In a sense, then, the experience of "void" is integral to being human at all; it is the result of being finite creatures that contain, or in sense are, a desire for a transcendent, inaccessible good. ${ }^{22}$ The "void" is the "immeasurable gulf" between the transcendent good that we desire, and the finite world, dominated by "necessity", which is our home. ${ }^{23}$ As a result, she is deeply suspicious of religious notions - for example, various doctrines concerning life "after" death - that can function so as to allow the needy ego to evade the contradiction of its own existence, because the saving truth lies in this contradiction. Without the acceptance of this "immeasurable gulf", one has no real sense of what the good is; in in Weil's terms, one conceives good at the wrong "level". Any idea or doctrine that encourages one to do this is deeply suspect. One of the more memorable remarks in Gravity and Grace reads:

We must leave on one side the beliefs which fill up voids and sweeten what is bitter. The belief in immortality. The belief in the utility of sin: etiam peccata. The belief in the providential ordering of events - in short, the "consolations" which are ordinarily sought in religion. ${ }^{24}$

Put more positively, the point, for Weil, is not to arrive at a fixed set of conceptions of life, death and purpose, but rather try to find a way of using concepts as opportunities for a certain kind of contemplation and encounter with reality. ${ }^{25}$ One can contemplate the truth of atheism and the truth of theism in different ways, because each may involve a genuine challenge to the settled beliefs that in different ways cushion one from real contact with the world. ${ }^{26}$ For Weil, contradictions can be 
experienced and contemplated in such a way that one is "drawn upwards", but it is not so much the internal content of any particular contradiction that represents its value, but rather the nature of our confrontation with it - the "resistance" it offers to us (see the quotation from "Forms of the Implicit Love of God" below for more on "resistance"). ${ }^{27}$ Hence the significance of the acceptance of death: we are finite mortals oriented towards the eternal; this is the experienced "impossibility" of our existence. By contemplating this, we experience the impossibility of desire, and in the process one may be fundamentally de-centred, or made to "look up and wait". 28

\section{The Pattern of Mystical Transformation}

The question of what happens when one has "looked up, and waited" will be considered next, through a reading of Weil's reflections on the nature of spiritual transformation. As we will see, I believe that some of the questions that emerge from these reflections are very similar to those that were raised in relation to the gospel sayings above.

In her luminous short essay "Some Reflections on the Love of God" Weil articulates the heart of her understanding of spiritual awakening in terms of an acceptance of death:

It is not for man to seek, or even to believe in, God. He has only to refuse his love to everything which is not God. This refusal does not presuppose any belief. It is enough to recognise, what is obvious to any mind, that all the goods of this world, past, present and future, real or imaginary, are finite and limited and radically incapable of satisfying the desire which burns perpetually within us for an infinite and perfect good. All men know this, and more than once in their lives they recognise it for moment, but then they immediately begin deceiving themselves again so as not to know it any longer, because they feel that if they knew it they could not go on living. And their feeling is true, for that knowledge kills, but it inflicts a death which leads to a resurrection. But they do not forsee that beforehand; all they forsee is death; they must either choose truth and death or falsehood and life. ${ }^{29}$

It is noteworthy that although at this juncture Weil refers to a Platonic imperative - to "turn away with your whole soul from the things that pass"- she frames her allegiance to this imperative in Christian terms: death leads to resurrection, not immortality. Despite this, however, her discomfort with "resurrection" is very apparent, and as soon as she introduces this term, she immediately qualifies it: "they do not foresee that beforehand; all they foresee is death". This qualification has to do with perspective; there is a difference between the "choice" she describes as it really is, and the choice as it is perceived by "all men" (sic). The "resurrection" that is spoken of here cannot be foreseen as resurrection, it can only be foreseen as death, and hence it is death that one must learn to accept; there is a strange sense in which spiritual life means learning to prefer death to life. However, this 
disciplining of one's desire is not sufficient, and Weil goes on to say that spiritual "advance" is not gained through activity, but through patient, receptive waiting:

A little child who suddenly perceives that he has lost his mother in the street runs about, crying, in all directions; but he is wrong. If he had the sense and courage to stay where he is and wait, she would find him sooner. We must only wait and call out. Not call upon someone, while we still do not know if there is anyone; but cry out that we are hungry and want bread. Whether we cry for a short time or a long time, in the end we shall be fed, and then we shall not believe but we shall know that there really is bread. What surer proof could one ask for than to have eaten it? But before one has eaten, it is neither needful nor particularly useful to believe in bread. What is essential is to know that one is hungry; and this is not belief, it is absolutely certain knowledge which can only be obscured by lies. All those who believe that food exists, or will one day be produced in this world, are lying.

So we can now see that there may be a deeper reason for Weil's reluctance to concern herself with the idea of resurrection; not only is the idea dangerously close to a crude and sensationalist supernaturalism, it may also be an unhelpful diversion of attention. In Weil's terms, it is easy to imagine various kinds of bread, but immensely difficult to face up to spiritual/metaphysical hunger, and so religious ideas that encourage the imagination to anticipate fulfilment in particular forms may be dangerous distractions, all too willingly embraced. More than this, however, Weil explores the idea that when it comes to the desire for the good, desire is its own satisfaction: when all the desire in the soul has been detached from earthly goods, "on that day I shall possess the sovereign good ... desiring in itself will be my good"). ${ }^{30}$ This realisation, in fact, is part of what the spiritual transformation that she is concerned with consists in. ${ }^{31}$

However, what Weil does not seem to take note of here is that although it may not be particularly "useful" to believe in bread before one has eaten, at the same time we might say that "hunger" is inescapably intentional; it is hard to make sense of what it would even mean to know that one is hungry without some implicit conception of satiety. At the very least, it would be hard to see how the metaphor could do much work here if the distinction between the state of being hungry and the state of being satisfied was to be lost altogether, just as the synoptic saying relies on the desire for life, and the real difference between losing and saving it. ${ }^{32}$ And so it seems as though the metaphor she uses - which, with all its gospel resonances carries much of the force of the thought here — pulls in a different direction to some of the intellectual tendencies evident elsewhere. ${ }^{33}$

The logic of the first extract from "Some Reflections on the Love of God" is repeated at several key passages in her notebooks, most notably in the Marseilles notebook:

"The world is a closed door. It is a barrier, and at the same time it is the passage way. 
If we want only the absolute good, that is to say, if we reject all the existing or possible, sensible, imaginary or conceivable good that is offered us by creatures as being insufficient; if we prefer to choose nothing at all rather than all that, then (with time), being turned toward that which we cannot possibly conceive, a revelation of it comes to us - the revelation that this nothingness is really the fullest possible fullness, the main-spring and principle of all reality. Then we can truthfully say that we have faith in God." ${ }^{34}$

In both cases the movement involves a painful acceptance, or endurance, but there is a small but important conceptual difference concerning the positive moment. This can be seen in comparison between the crucial phrases in each: in the essay, we read that there is a knowledge that kills, but that it "inflicts a death which leads to a resurrection"; in the notebooks we read that if we reject all conceivable goods, and wait, then a revelation comes, "the revelation that this nothingness is really the fullest possible fullness." The difference seems to be between transformation, in which that which has died is resurrected in a transformed state (through the provision of 'supernatural bread"), and a dramatic and liberating shift in perspective (in which nothingness is shown to have been-all along, presumably_fullness).

The beginning of "Some Reflections on the Love of God" can be seen as an exhortation for honesty concerning the difference between desire and fulfilment, or between hunger and satiety. The path to spiritual transformation is, according to Weil, remarkably simple: to admit the insatiable nature of the desire that "burns perpetually within", and then to "wait". Somehow, the honesty required to admit to this hunger, and the patience required to "wait" is rarer than one might expect (and here the fourth beatitude is clearly in the background). But the logic of the extract from the notebooks above is to suggest that there is a perspective from which the difference between hunger and satiety disappears, insofar as "void" is shown to have been "the fullest possible fullness". Weil seems overwhelmingly to favour the latter approach in her thought (in which the mystical moment is a shift in perspective, which dissolves certain distinctions), but my suggestion here is that there are good reasons to pay attention to the "traces" of the former (in which there is transformation, and the difference between hunger and bread is maintained).

A similar issue can be discerned in an entry that concerns time. For Weil, "time", like death, is both a sign of our finitude, and the root of sinful attempts to escape from our condition; this is most often explored in relation to periods of intense suffering, in which the passage of time is felt as an inescapable curse. For Weil, when the time of suffering is accepted and loved as time, it opens out onto "eternity", just as death accepted as death leads to life: "[i]f one behaves as though dead, the Lord comes and brings life from on high. ... Total obedience to time obliges God to bestow eternity. ${ }^{, 35}$ There is a strange dynamic here: abundance is glimpsed, or given, only once scarcity is accepted. But, again, it is not clear whether Weil has in mind something like an unveiling or dramatic 
shift in perspective, in which time is found to be eternity, just as emptiness was found to be fullness; or something more like a transformation, in which eternity overcomes the finitude of time. Forms of understanding based on either could be accused of "sweetening what is bitter" or providing false consolation: if one believes that one can, somehow, become reconciled with death and temporal finitude through a shift in perspective, one may thereby sweeten the bitterness; if one believes that suffering is a temporary trial and that heavenly relief awaits in a God-given future, one might never taste the bitterness in the first place. Weil's tendency to resolve the ambiguity in the direction of the former raises the suspicion that at times her own thought a tendency of resolving contradictions too hastily, rather than "waiting" with them.

In an excellent essay on Weil concept of "decreation", J. P. Little briefly suggests a criticism of Weil that, in my view deserves greater attention, and which I hope will shed some light on the issues we are concerned with here. As has already been mentioned, for Weil, creation is seen as an act of abdication, in which God consents to be less than everything; and in this sense, 'decreation' is the process by which, through acceptance of our essential nullity, autonomous creatures imitate this abdication, by 'refusing to be'. ${ }^{36}$ Little goes on to explore the role of this concept in Weil's thought, with particular reference to her dualistic conception of the self, which consists of the autonomous ego that says "I" and the "uncreated", eternal core. In passing she notes that there is a parallel between the metaphysics that Weil develops and her own judgement of the "desire for equilibrium": "Our human response to God, decreation replying to creation, amounts to an almost necessary reciprocity, a symmetry indicative of Simone Weil's need in this, as in many other areas of her thought, to restore a balance that has been disturbed by the assertion of the autonomous self." ${ }^{\prime 37}$ The possibility is raised, then, that Weil may have provided the conceptual tools necessary to critique some of her own more extreme metaphysical speculations.

In my view, it seems as though the ambiguity between the two ways of understanding the mystical moments in Weil's thought — perspective and transformation — may actually be a fertile ambiguity, but very often Weil seems to resolve the ambiguity in one direction, as already discussed. In some respects it seems as though the effect of this is to restore a certain kind of balance: the truth of desire is that it is its own aim; the truth of our finitude and death is that this is our fulfilment; the truth of the loved one's absence is their presence; the truth of our existence is its essential nullity. In short, all that seems to negate being, vitality or relationality becomes a "draught of immortality" once faced and accepted. ${ }^{38}$ But perhaps the effect of this is actually is to reduce the sense that to be human is to be essentially unfinished, and open. The gospel saying with which we began appears to maintain the sense that the "gain" of one's life may lie ahead, even as it also suggests a complete upheaval of the difference between gain and loss. Weil's work, it appears to me, is often animated by a similar tension, and yet Weil's tendency is to tip the balance in favour of a mystical transformation of perspective, which can be rationally comprehended. Little suggest that Weil's own metaphysics may 
be tainted by the search for equilibrium; my argument here is that at times she is guilty of resolving some of the most fertile ambiguities that her work expresses slightly too quickly, in search of purity.

\section{Conclusion}

The notebooks, short essays and letters that contain this rich legacy are complicated and unfinished, and moreover, Weil herself is not unaware of some of the conflicts and tensions that emerge from them, and did not intend to provide a final schematic account of them. Nevertheless, the set of ideas with which I have been concerned appear frequently enough to be considered a central part of her thought, and one of her key concerns: to articulate the essential shape or pattern of mystical revaluation. In the brief discussion above, I have tried to show that there is a conceptual conflict apparent in the important passages that describe this pattern. Weil seems to have experimented with her own way of resolving this issue, and others like it through two ideas: firstly, that some beliefs should be held "in secret" and are self-refuting as soon as they are known or held consciously (because loss is not really loss if it known to really be gain); ${ }^{39}$ secondly, the idea that there are different "levels" of affirmation, meaning that some truths can be false if conceived at the wrong "level". ${ }^{40}$ These ideas are deeply intriguing and profound in their own right. My suggestion is simply that the ambiguity may have been more important and more fundamental to Christian thought, than Weil realised, and that this may have something to do with the meaning of the resurrection; a subject that she devoted relatively little attention to, and seems to have dismissed rather too easily. A rare reflection from Weil's "New York Notebook" that gestures in the direction I have in mind will have to serve as a final word:

The resurrection is Christ's pardon to those who killed him, the evidence that in doing him the greatest possible harm they did him no harm. [. . .] The joy of Easter is not the joy that comes after pain, like freedom after chains, repletion after hunger, or reunion after separation. It is the joy that soars above pain and perfects it. [...] Pain is the contrary of joy; but joy is not the contrary of pain. ${ }^{41}$

\footnotetext{
${ }^{1}$ Simone Weil, Gateway to God, ed. David Raper (Glasgow: Fontana, 1974), 129.

${ }^{2}$ Simone Weil, The Notebooks of Simone Weil, trans. Arthur Wills (London: Routledge and Kegan Paul, 1956), 166.

${ }^{3}$ Simone Weil, First and Last Notebooks, trans. Richard Rees (London: Oxford University Press, 1970). 70.

${ }^{4}$ Weil, First and Last Notebooks, 213.
} 
${ }^{5}$ Weil, Notebooks, 494.

${ }^{6} \mathrm{Mk}$ 8:36 (NRSV). See also variants in Mt 10:39, 16:25, Lk 9:24 and 17:33, plus Jn 12:25.

${ }^{7}$ The Lucan version of the beatitudes renders this problem more acutely: it is not simply the poor "in spirit" to whom the kingdom already belongs, but simply the poor; wealth, satiety and laughter are signs that one has nothing good left to receive, that one has already received one's reward.

${ }^{8}$ See Phillipa Foot's essay on Nietzsche's "revaluation of values" on this simple but important point in Virtues and Vices and Other Essays in Moral Philosophy (Berkeley and Los Angeles, California: University of California Press, 1978) 81-95

${ }^{9}$ Simone Weil, Gravity and Grace, trans. Emma Crawford and Mario von der Ruhr (London: Routledge, 1999), 10. Where possible I have tried to provide references to Gravity and Grace rather than the notebooks that for ease of reference.

${ }^{10}$ Weil, Gravity and Grace, 6.

${ }^{11}$ Weil, Notebooks, 553.

${ }^{12}$ Weil, First and Last Notebooks, 97-8.

${ }^{13}$ Weil, Notebooks, 554.

${ }^{14}$ Weil, Gravity and Grace, 12.

${ }^{15}$ Weil, Gravity and Grace, 15 ; Notebooks

${ }^{16}$ This point is consonant with James Alison's description of resentment as a warding off of death, the attempt to re-affirm the value of one's life over and against the threat of death. See "Theology Among the Stones and

Dust" in Theology and Sexuality, 11 (1999), 91-114.

${ }^{17}$ Weil, Gravity and Grace, 22.

${ }^{18}$ For more detailed discussions of Weil's use of the term "void”, see Miklos Veto, The Religious Metaphysics of Simone Weil, trans. Joan Dargon (Albany: State University of New York Press, 1994), chapter 3; A. Rebecca Rozelle-Stone and Lucian Stone, Rozelle-Stone, Simone Weil and Theology (London: Bloomsbury, 2013), chapter 3; and Lissa McCullough, "The Void: Simone Weil's Naming of Evil” in Wrestling with God and with Evil: Philosophical Reflections, ed. Hendrik M. Vroom (Amsterdam: Rodopi, 2007), 22-42.

${ }^{19}$ For the clearest statement of this idea, see the beginning of "Draft for a Statement of Human Obligations", in Simone Weil: An Anthology, ed. Siân Miles (New York: Weidenfeld \& Nicolson, 1986).

${ }^{20}$ Weil, Notebooks, 489.

${ }^{21}$ See, e.g. Weil, Notebooks, 175.

${ }^{22}$ See Weil, Notebooks , 489 ; First and Last Notebooks, 308

${ }^{23}$ Eric Springsted, Simone Weil and The Suffering of Love (Cambridge, MA: Cowley Publications, 1986). 41.

${ }^{24}$ Weil, Gravity and Grace, 13.

${ }^{25}$ See Eric O. Springsted's "Mystery and Philosophy" in The Relevance of the Radical, ed. A. Rebecca Stone and Lucian Stone (London: Continuum, 2010) for a good summary of Weil's thought on this issue.

${ }^{26}$ This can be seen from a particularly interesting entry in the Marseilles notebook:

The three conceptions, first that of annihilation in the sense understood by atheists, secondly that of reincarnation and purgatory, and thirdly that of paradise and hell - all three of which are indispensable for pondering on the subject of death - can very well be accepted as true and conceived of simultaneously if we 
bear in mind the fact that death lies at the point of intersection between time and eternity. They only seem incompatible to us because we cannot prevent ourselves from visualizing eternity as a duration.

All three are necessary. Reincarnation and purgatory mask the truth that this life is unique, irreparable, the only one in which we can either be lost or saved. Paradise and hell mask the truth that salvation is solely the accompaniment of perfection, and damnation solely the accompaniment of betrayal, and that the soul which is imperfect, but nevertheless turned in the direction of good, is not susceptible of either the one or the other. The materialistic notion of annihilation shuts out the essential, primordial truth that the one and only need of the soul is salvation, and that the whole meaning of life lies in making preparation for the moment of death. The belief in immortality breaks up the pure bitterness and the reality itself of death, which remains for us the most previous gift bestowed by divine Providence. (Weil, Notebooks, 467-8).

Her point suggests that she had begun to view materialistic atheism as — at least potentially — as "evasive" as certain forms of theism, despite the fact that she vows that one cannot be materialist enough when contemplating human society.

${ }^{27}$ André Devaux 'On the use of contradiction in Simone Weil' in Simone Weil's Philosophy of Culture, Readings Towards a Divine Humanity, ed. Richard H. Bell (Lanham: Rowman \& Littlefield Publishers, 1993), 151-2.

${ }^{28}$ Weil, Notebooks, 412.

${ }^{29}$ Weil, Gateway to God, 85. See the parallel passage in the Notebooks, 492: "If we want only the absolute good, that is to say, if we reject all the existing or possible, sensible, imaginary or conceivable good that is offered us by creatures as being insufficient; if we prefer to choose nothing at all rather than all that, then, (with time), being turned toward that which we cannot possible conceive, a revelation of it comes to us - the revelation that this nothingness is really the fullest possible fullness, the main-spring and principle of all reality. Then we can truthfully say that we have faith in God."

${ }^{30}$ Weil, First and Last Notebooks, 316.

${ }^{31}$ See Stone and Stone, Simone Weil and Theology, 172-177 for a discussion of this passage in relation to Weil's conception of undirected attention/desire without an object.

${ }^{32}$ I am indebted, here, to Rush Rhees' discussion of Weil's use of the term "obedience" to describe the necessities of the natural world. Although the problem he raises is thematically different, the criticism has a similar-Wittgensteinian — form to the one I put forward here. See Rush Rhees, Discussions of Simone Weil, ed. D. Z. Philips, ass. Mario von der Ruhr (Albany: State University of New York Press, 2000), 57-58.

${ }^{33}$ Weil's reflections on "moral faith", which seem to propose something similar to Kant's "postulates" in The Critique of Practical Reason, are also relevant here. Weil argues that anyone who believes that the desire for the good is never in vain, regardless of how they might consider themselves, has faith. See, e.g. Weil, First and Last Notebooks, 138.

${ }^{34}$ Weil, Notebooks, 492

${ }^{35}$ Weil, First and Last Notebooks, 110.

${ }^{36}$ See J. P. Little, “Simone Weil's Concept of Decreation” in Simone Weil's Philosophy of Culture, Readings Towards a Divine Humanity, 27.

${ }^{37}$ Little, "Simone Weil's Concept of Decreation", 28.

${ }^{38}$ Weil, Notebooks, 61. 
${ }^{39}$ Weil, First and Last Notebooks, 122.

${ }^{40}$ Weil, First and Last Notebooks, 179.

${ }^{41}$ Weil, First and Last Notebooks, 69. 